\title{
EVALUATION OF LECTURER PERFORMANCE (REVIEWED FROM CERTIFICATION AND WORK EXPERIENCE IN THE SULTHAN THAHA SYAIFUDDIN STATE ISLAMIC UNIVERSITY JAMBI)
}

\author{
Firdaus Zuhri
}

Lecturer of Syekh Maulana Qori Islamic College, Bangko, Indonesia

\begin{tabular}{|c|c|}
\hline $\begin{array}{l}\text { ARTICLE INFORMATION } \\
\text { Received : 01/09/2019 } \\
\text { Revised : 11/09/2019 } \\
\text { Issued: } 21 / 09 / 2019\end{array}$ & $\begin{array}{l}\text { Abstract: The purpose of this study was to determine } \\
\text { the performance of lecturers in terms of certification and } \\
\text { work experience at Sulthan Thaha Syaifuddin State } \\
\text { Islamic University Jambi. This study uses a comparative } \\
\text { quantitative approach or expost-facto, where two-way } \\
\text { ANAVA as a statistical analysis method is used to prove } \\
\text { the causal relationship between variables. The research } \\
\text { hypothesis that was built was that lecturer certification, } \\
\text { work experience affect lecturer performance. Random } \\
\text { sampling is a sampling technique used on } 96 \text { lecturers as } \\
\text { respondents. The results showed that lecturer } \\
\text { certification, work experience affect the performance of } \\
\text { lecturers. } \\
\text { Keywords: Performance, Certification, and work } \\
\text { experience. }\end{array}$ \\
\hline
\end{tabular}

\section{INTRODUCTION}

Higher education institutions as higher education providers are required to be able to produce excellent graduates. These ideals can be achieved if supported by lecturers who are qualified and competent in carrying out the tridharma of higher education. Many research results state that the quality of higher education in Indonesia is still far from the expected standard. Higher education ratings are generally still low and cause for concern, so it takes a variety of ways to improve the condition. The Government through the Implementation of Republic of Indonesia Law Number 14 of 2005 concerning Teachers and Lecturers mandated lecturer certification with the aim of improving the quality, creativity and integrity of lecturers in the form of performance in order to be able to actualize their potential and carry out their consistency through efforts performance evaluation.

Evaluation in English evaluation can be understood as a systematic process for determining decisions about a program's objectives that have been implemented. The definition of evaluation put forward by experts. Among those proposed by Gronlund in Djaali (2008: 1) defines evaluation as a systematic process for determining or making decisions to the extent that 
the goals or programs have been achieved. Furthermore Cronbach and Stufflebeam in Arikunto (2012: 3) defines that the evaluation process is not merely measuring the extent to which the goal is achieved, but is used to make decisions. Meanwhile Wandt and Brown in Sudijono (2012: 1) Defines Evaluation refers to the act or process of determining the value of something. According to this definition, the term evaluation refers to or contains an understanding: an action or a process to determine the value of something. Sudijono also said that the evaluation includes two activities that have been stated previously, which include "measurement" and "assessment". Evaluation is an activity or process for assessing something.

Ralph Tyler in Tayibnapis (2008: 3) states that evaluation is a process that determines the extent to which educational goals can be achieved. This means that measurements need to be taken of the program to what extent the program has been carried out and the extent to which the achievement of the objectives of the education program is achieved. Dunn states that evaluation can be equated with appraisal, rating and assessment as an effort to analyze the results of policies. From the two opinions of Ralph Tyler and Dunn (2003: 608) it can be concluded that evaluation is the measurement and assessment of programs in achieving educational goals.

Furthermore Dunn argued that in evaluating the Policy can be done before (formative evaluation) and after (summative evaluation) the policy was carried out. Formative evaluations are carried out on ongoing programs, for example to prepare information for program improvement (information on staff responsibilities in improving lecturer performance). Summative evaluation prepares information on executing decisions or expanding a program (as a continuation of formative evaluation, whether performance measures need to be improved, whether monitoring programs should be continued).

It is also suggested that the main stem as a basis is (a) accountability as an activity planned to improve a program for the better, and (b) systematic social research is the root of the evaluating tree that comes from the use of a systematic set of assessment methods to establish accountability. From these two main branches, scientific and rational evaluation models are developed. The results are the three main branches, namely: (a) valuation, method and use.

From the several evaluation definitions put forward by some of the experts above, it can be concluded that evaluation is a process of activities systematically collecting, processing, analyzing and interpreting information obtained in a valid and reliable manner and then considered in making a decision whether a process needs to be improved, stopped or forwarded.

Performance according to the Indonesian Dictionary is something that is achieved. Whitmore (2002: 104) suggests the notion of performance as an act, an achievement or what someone shows through their real skills. Referring to this view, it can be interpreted that a person's performance is related to the routine tasks he does. As a lecturer, for example, her routine duties are teaching, researching, and doing community service. The optimal results achieved from the assignment are lecturers' performance.

Furthermore explained Cikmat (2002: 32) that a person's performance is influenced by two factors, namely (1) internal factors, and (2) external factors. Internal factors are related to people's characteristics, for example ability and effort. While the difficulties of duty and luck are external.

Still related to performance, Bernandin \& Russell as in Gomes (2003: 135) states that performance or performance is a record that results from the function of a particular job or activity for a certain period of time. On the other hand Bolt and Rummler in Cikmat suggest that 
performance may not be as expected if there are weaknesses between links between individuals, resources, task clarity, feedback, and consequences.

Good or bad performance is not only seen from the level of quantity that can be produced by someone at work, but also measured in terms of quality. Mangkunegara (2011: 45) says that performance is the result of quality and quantity of work achieved by someone in carrying out their duties according to the responsibilities given to them.

According to Deming in Dessler (2006: 322) basically employee performance is a function of training, communication, tools, and supervision rather than personal motivation. This means that Deming emphasizes performance management on goal setting, assessment, and integrated development, due to the increasing utilization of performance management as a result of the growing popularity of the Total Quality Management concept.

Nawawi (2011: 234) stated that the intended performance results of the implementation of a job, both physical / material and non-physical / non material. The physical / material work results are the results of tangible work that can be seen touched. If it is related to the performance of lecturers having physical / material characteristics including syllabus, lecture program units, modules, teaching materials, papers, research reports, and written papers. Non-physical lecturers' performance is an intangible performance, among others: ideas, concepts, and others.

According to Danim (2008: 70) that performance is a competency in action. This means that performance is seen as an integral part of competence. Competence is a set of knowledge, skills and basic values that are reflected in the habits of thinking and acting. Competence can also be defined as a specification of the knowledge, skills and attitudes that a person has and their application in work, in accordance with the performance standards of needs by the community and the world of work. The taxonomy of competency standards includes content standards, process standards and performance standards. Appearance standards regarding the appearance criteria. Referring to the three standards, performance is seen as an integral part of competence, even though competency and performance are different. Furthermore it is said that performance is influenced by three factors, namely: (1) knowledge, (2) skills, and (3) basic values.

Employee performance is an important thing in an organization's efforts to achieve its objectives, so that employee performance appraisal needs to be done. The purpose of evaluating employee performance in general is to provide feedback to the organization in an effort to increase organizational productivity and specifically carried out in relation to various policies towards employees such as promotional objectives, salary increases, education and training, and others. From some of the above theories it can be concluded that the performance of lecturers is the performance or work of lecturers who contribute to the achievement of organizational goals.

Certification comes from English, the word certification is Certification with the meaning of information, authorization, diploma, certificate, brevet. In the large Indonesian dictionary, the meaning of certification is very simple, namely certification. The definition of certification is mostly prepared by certification-related institutions, whether government, international institutions or institutions of cooperation between countries.

In this case government policy in the field of education must always refer to the Law of the Republic of Indonesia Number 20 of 2003 concerning the National Education System and the Government of the Republic of Indonesia Number 19 of 2005 concerning National Education Standards. The education policy issued by the Ministry of National Education in an effort to improve the quality of education includes lecturer certification. 
According to Abdul Wahab (2014: 6) the policy is often used interchangeably in political communication with other terms, such as goals, programs, decisions, laws, provisions, proposals, and grand designs made by government. Lecturer certification is an implementation of educational policy that aims to improve the professionalism of educators in carrying out their duties. Education policy is one of public policies.

Educational policy is the whole process and the results of the formulation of educational strategic steps outlined in the vision and mission of education, in order to realize the achievement of educational goals in a society for a certain period of time. Thus, policies basically contain the meaning of goals and ways of working. Law Number 14 of 2005 concerning Teachers and Lecturers is an educational policy in the context of improving the quality of education. In primary and secondary education, the policy is implemented in the teacher certification program, while in higher education is realized in the lecturer certification program. So the target of the lecturer certification program is teaching in higher education, while the target is to increase lecturer productivity from its performance.

Based on the description above, what is meant by lecturer certification in this study is the granting of educator certificates to lecturers as a recognition of the professionalism of lecturers in carrying out the three-tridharma of higher education, after going through a competency test conducted with a portfolio.

Experience is that which has been experienced (lived, felt, borne). According to Dewey, as in Kurnia (2006: 28) experience is an overall complex and multi-faceted activity and result of active human interaction, as a living creature that is aware and growing, with its surrounding environment constantly changing in the course of history.

In general, experience is said to be something that has been done in life, knowledge or skills obtained from doing or seeing something. In addition, experience can also be interpreted as active participation in activities, the result of accumulation of knowledge and skills.

Suriasumantri (2000: 51) mentions empiricists that human knowledge is not obtained through abstract rational reasoning but through concrete experience. Experience is also interpreted as knowledge and skills possessed, events or series of events that are followed or passed.

Gestalt in Sudjana (1991: 26) extends experience as a purposeful interaction. Whereas Sudjana's own opinion of experience is the interaction of organisms with their environment. Also reinforced by Nasution (1995: 75) experience is interaction, namely the action and reaction between individuals undergoing environmental influences, so the action of the environment on the individual, and vice versa the individual reacts to that environmental influence. This means that through activities or work people gain experience and knowledge, that knowledge gives rise to an understanding of an object, a creature, a phenomenon, a proposition, a useful theory.

According to Witherington as in Ocin (2011: 54) experience is experiencing the real situation and reacting sincerely to various aspects of the situation to achieve a real goal. This illustrates that the experience is a basic element in the process of achieving goals and as a guide to implement them. Situations that occur and are felt to be able to improve and accelerate the activities carried out to achieve the goals set.

Based on subsequent opinion Ricard (1994: 55) experience is the basis for obtaining new ideas and behaviors that provide insight, understanding and ways that are difficult to describe to someone who does not experience the same thing. For someone to arrive at a state of experience and connect what has been experienced and what is learned from what they experienced. 
Experience is a direct practice and the experience gained in the form of theory applies to all jobs, including teaching work for a lecturer.

Experience is also often called a good teacher, meaning that from experience someone will learn a lot and gain a lot of knowledge that is not only obtained from the teacher in the school. As the opinion of Bernadib in Salamah (2003: 78), that experience is a joint to a knowledge.

Experience is concluded as something that has been done in life, a series of events that are followed or passed, knowledge, skills that are found from doing or seeing something.

The work experience referred to in this study is the lecturer working period in carrying out his duties as a lecturer in tertiary institutions in accordance with the assignment letter from the authorized institution (government) for periods of more than ten years and under ten years.

The purpose of this study was to determine the effect of certification and work experience at Sulthan Thaha Syaifuddin State Islamic University Jambi.

\section{RESEARCH METHODS}

This study uses a comparative quantitative approach or expost-facto, where two-way ANAVA as a statistical analysis method is used to prove the causal relationship between variables. The research hypothesis is that lecturer certification, work experience affects the performance of lecturers. Random sampling is a sampling technique used on 96 lecturers as respondents.

The research population was all the lecturers of the Sulthan Thaha Syaifuddin State Islamic University Jambi, namely lecturers who had an educator certificate (A1) and lecturers who did not yet have an educator certificate (A2) as independent variables. Work Experience> 10 years $\left(B_{1}\right)$ and work experience $<10$ years $\left(B_{2}\right)$ as the attribute variable (level), while as the dependent variable is the performance of the lecturer. The following designs or experimental designs are presented as shown in table 1. Below:

Table 1. Research Design

\begin{tabular}{ccc}
\hline \multirow{2}{*}{$\begin{array}{c}\text { Work experience } \\
(\mathrm{B})\end{array}$} & \multicolumn{2}{c}{ Certification $(\mathrm{A})$} \\
\cline { 2 - 3 } & $\begin{array}{c}\text { Has an Educator Certificate } \\
\left(\mathrm{A}_{1}\right)\end{array}$ & $\begin{array}{c}\text { Not yet have an Educator Certificate } \\
\left(\mathrm{A}_{2}\right)\end{array}$ \\
\hline $\begin{array}{c}\text { Work Experience }>10 \text { years } \\
\left(\mathrm{B}_{1}\right)\end{array}$ & $\left(\mathrm{A}_{1} \mathrm{~B}_{1}\right) \mathrm{Y}_{111}: \mathrm{Y}_{11} \mathrm{n}_{1}$ & $\left(\mathrm{~A}_{2} \mathrm{~B}_{1}\right) \mathrm{Y}_{121}: \mathrm{Y}_{12} \mathrm{n}_{2}$ \\
\hline $\begin{array}{c}\text { Work Experience }<10 \text { years } \\
\left(\mathrm{B}_{2}\right)\end{array}$ & $\left(\mathrm{A}_{1} \mathrm{~B}_{2}\right) \mathrm{Y}_{211}: \mathrm{Y}_{21} \mathrm{n}_{3}$ & $\left(\mathrm{~A}_{2} \mathrm{~B}_{2}\right) \mathrm{Y}_{221}: \mathrm{Y}_{22} \mathrm{n}_{4}$ \\
\hline
\end{tabular}

Data collection through the instrument of lecturer performance. The construct validity is validated by the expert while the empirical validity is with the product moment correlation. In the education and teaching questionnaire out of 36 items 35 are valid and 1 is invalid. In the research field of 69 item items there are 60 valid and 9 invalid. In the field of community service, 58 items have 54 valid items and 4 invalid items. The instrument used questionnaire performance lecturers in the field of education and teaching has a reliability value of 0.82058 . the research field has a reliability of 0.892772 . Field of community service with a reliability of 0.887815 .

Data analysis (1) descriptive (2) prerequisite test for inferential analysis, normality test using Liliefors test and homogeneity test using fisher test and Bartlett test (3) Inferential data 
analysis to test hypotheses using Two Way ANAVA. Meanwhile, to find out the significance of the differences of each treatment group, further tests were carried out using the t-Dunnet test, if the number of samples for each group was the same, continued by the simple effect test with the Scheffie Test.

\section{FINDINGS AND DISCUSSION}

ANAVA $\mathrm{F}$ test results about differences in the average performance of lecturers are summarized in table 2 below:

Table 2. Summary of Two-way ANAVA Results with Test F About Differences in Average Lecturer Performance (Y)

\begin{tabular}{crrrrl}
\hline Source of Variance & \multicolumn{1}{c}{ JK } & Df & \multicolumn{1}{c}{ RJK } & \multicolumn{1}{c}{ F } & Sig \\
\hline $\mathrm{A}$ & 27023.824 & 1 & 27023.824 & $13.230^{*}$ & .000 \\
\hline $\mathrm{B}$ & 9633.104 & 1 & 9633.104 & $4.716^{*}$ & .032 \\
\hline $\mathrm{A} * \mathrm{~B}$ & 23943.015 & 1 & 23943.015 & $11.722^{*}$ & .001 \\
\hline Error & 187914.615 & 92 & 2042.550 & & \\
\hline Total & 22707491.000 & 96 & & & \\
\hline Total Corrections & 248912.990 & 95 & & & \\
\hline
\end{tabular}

From the data source variance $\mathrm{A}$ in Table 2 above, it can be seen that Fcount $=13,230$ with a significance of 0,000 which indicates that there are differences in performance between groups of lecturers who have educator certificates and groups of lecturers who do not yet have an educator certificate. The average shows the performance of lecturers who already have a teacher certificate is higher $(X=499,979)$ compared to the performance of lecturers who do not have an educator certificate $(X=467,375)$, meaning that the performance of the group of lecturers who have an educator certificate is higher than the performance of groups of lecturers who do not yet have educator certificate.

Then the source of variance $B$ shows the value of $F$ that Fcount $=4.716$ with a significance of 0.032 (small than 0.05) means that there are differences in performance between groups of lecturers who have over 10 years experience with groups of lecturers who have experience under 10 years. The average shows the performance of lecturers who have over 10 years of experience $(X=499,725)$ compared to the performance of lecturers who do not have an educator certificate $(X=472,214)$, meaning that the performance of groups of lecturers who have over 10 years experience is higher than the performance of the lecturer group has experience under 10 years.

Then the source of variance $\mathrm{A} * \mathrm{~B}$ shows the value of Fcount $=11.722$ with a significance of 0.001 (small than 0.05), meaning that there is an influence of interaction between certification status with work experience on lecturer performance. This requires a simple test of the effect with the Scheffe test.

The results of the calculation of further tests using the Scheffe test can be seen in Table 3 below:

Table 3. Calculation of the Scheffe Test

\begin{tabular}{cccc}
\hline Group & \multirow{2}{*}{$\mathrm{Dk}$} & $\mathrm{F}_{\text {count }}$ & $\mathrm{F}_{\text {table }}$ \\
\cline { 3 - 4 } & & & $\alpha=0,05$ \\
\hline $\mathrm{A}_{1} \mathrm{~B}_{1}: \mathrm{A}_{1} \mathrm{~B}_{2}$ & $3 ; 92$ & 21,19 & $3 ; 92$ \\
\hline $\mathrm{A}_{1} \mathrm{~B}_{2}: \mathrm{A}_{2} \mathrm{~B}_{2}$ & $3 ; 92$ & 0,03 & $3 ; 92$ \\
\hline $\mathrm{A}_{1} \mathrm{~B}_{1}: \mathrm{A}_{1} \mathrm{~B}_{2}$ & $3 ; 92$ & 16,63 & $3 ; 92$ \\
\hline $\mathrm{A}_{2} \mathrm{~B}_{1}: \mathrm{A}_{2} \mathrm{~B}_{2}$ & $3 ; 92$ & 0,74 & $3 ; 92$ \\
\hline
\end{tabular}


Calculation of the table above shows that in groups A1B1 and A1B2 $F_{\text {count }}>F_{\text {table }}(21.19)>$ (2.704) at a significant level $\alpha=0.05$ means that the performance of lecturers among those who have educator certificates and work experience above 10 years is higher than lecturer performance that does not yet have an educator certificate and work experience above 10 years. The same thing is also shown in the A1B2 and A2B2 groups $\mathrm{F}_{\text {count }}<\mathrm{F}_{\text {table }}$ ie $(0.03)<(2.704)$ at a significant level $\alpha=0.05$ means that the performance of lecturers among those who have educator certificates and work experience under 10 years is relatively the same than lecturer performance that does not yet have an educator certificate and work experience under 10 years. In the A1B1 and A1B2 groups $F_{\text {count }}>F_{\text {table }}$ ie (16.63)> (2.704) at a significant level $\alpha=0.05$, the performance of lecturers among those who have educator certificates and work experience above 10 years is higher than the performance of lecturers who already have Educator's certificate and work experience under 10 years. then in the A2B1 and A2B2 groups $F_{\text {count }}<F_{\text {table }}(0.74)<(2.704)$ at a significant level $\alpha=0.05$, the performance of lecturers among those who do not yet have an educator certificate and work experience above 10 years is relatively the same compared to the performance of lecturers who have not have educator certificates and work experience under 10 years.

\section{The First Hypothesis}

Based on the results of testing the hypothesis Ho rejected, tested hypothesis. This shows that the performance of lecturers who have educator certificates has a higher performance compared to lecturers who do not have educator certificates.

Lecturer certification is one of the government's policies. Lecturer certification is a program that aims to improve the quality, creativity and integrity of lecturers to be able to do their job. Lecturers who already have an educator certificate are professional lecturers.

In the Educational Certification Handbook for Lecturers in 2010 stated that educator certification is the process of providing educator certificates for lecturers. Lecturer certification aims to (1) assess the professionalism of lecturers in order to determine the eligibility of lecturers in carrying out their duties, (2) protect the teaching profession as an agent of learning in higher education, (3) improve the process and results of education and (4) accelerate the realization of national education goals.

One of the goals of lecturer certification is to assess the professionalism of lecturers, and of course a professional is ready to be evaluated, and open, in accordance with Payong's theory that a professional is a person who is always open and responsive to various changes, especially those related to his professional field. As a professional educator the lecturer must make a Lecturer Workload Plan which is carried out in one semester. Lecturers who have educator certificates have proven their competence and will be evaluated their performance every semester through the Lecturer Performance Report.

Relevant research that supports this is research conducted by Sihotang, on "The Effect of Lecturer Certification and Self Concepts on the Performance of Kopertis Region III Jakarta Private University Lecturers". Sihotang stated that the results of the research show that the performance of lecturers who have had an educator certificate is higher than the performance of lecturers who do not have an educator certificate.

This shows that the implementation of lecturer certification is in accordance with the expectations of government policy. The government makes a certification policy with the aim that lecturers in carrying out their duties are professional so they are entitled to receive rewards. Thus based on theory and research results show that certification has a significant effect on lecturer performance.

\section{The Second Hypothesis}

Based on the results of testing the hypothesis Ho rejected, tested hypothesis. This shows that the performance of lecturers who have work experience above 10 years is higher than the 
performance of lecturers who have work experience is under 10 years. Experience is said to be something that has been done in life or knowledge, skills gained from doing or seeing something. This shows that experience makes someone more skilled. The lecturer who has long worked will be more familiar with everything related to his assignment, so he will get a lot of experience about his assignment, and this experience will become knowledge for him. The more frequent things repeat, the more skill and mastery that is concerned with it, according to the Suriasumantri theory argues that human knowledge is not obtained through abstract rational reasoning but through concrete experiences.

Research relevant to supporting this is research conducted by Kurnia, on "Teacher's Teaching Ability: The Relationship between Achievement Motivation, Attitudes Towards Profession and Teaching Experiences with Teacher's Teaching Ability". Kurnia stated that the results of the research showed that teaching experience had an effect on the teaching ability of the teacher as well as lecturers. This shows that lecturers who have work experience will carry out tasks responsibly. On the other hand, a lecturer who does not have work experience then carries out the task just as an obligation. Thus based on the theory and results of the study indicate that work experience has a significant effect on the performance of lecturers.

\section{The Third Hypothesis}

Based on the results of testing the hypothesis Ho rejected, tested hypothesis. This shows that there is an interaction between certification and work experience on the performance of lecturers. Lecturers who have been certified mean that they also have work experience because of the requirements to be proposed to become a participant in lecturer certification selection. Thus based on the theory and the results of the study show that certification and work experience of lecturers together affect the performance of lecturers.

\section{The Fourth and Fifth Hypothesis}

Based on the results of testing the fourth hypothesis Ho is rejected, the hypothesis is tested. This shows the performance of lecturers between lecturers who have had an educator certificate and work experience above 10 years is higher than lecturers who do not have an educator certificate and work experience over 10 years. The group of lecturers who have work experience above 10 years of certification has given motivation and new insights to lecturers in terms of competency development. Thus based on the theory and research results show that there are significant differences in the performance of lecturers.

In contrast to the fourth hypothesis, the fifth hypothesis is based on the results of testing the hypothesis not tested. This shows the performance of lecturers among those who have educator certificates and work experience under 10 years is relatively the same as the performance of lecturers who do not have educator certificates and work experience under 10 years. In the lecturer group under 10 years of work experience, lecturers consider certification merely as an effort to improve the welfare of lecturers rather than improving performance and understanding is still low so that the influence is small and the difference is not significant.

\section{The Sixth and Seventh Hypothesis}

Based on the results of the sixth hypothesis testing, the hypothesis is tested. This shows the performance of lecturers between those who already have an educator certificate and work experience above 10 years is higher than the performance of lecturers who have had an educator certificate and work experience under 10 years. In the group of lecturers who have educator certificates, certification supports the professionalism of lecturers so that performance is better and lecturers try to fulfill their duties well and the existence of these rewards affects the 
performance of lecturers. There are no theories and research that are relevant to this research. Thus based on the results of the study indicate that there are significant differences in the performance of lecturers.

In contrast to the sixth hypothesis, the seventh hypothesis is untested. This shows the performance of lecturers between those who do not have an educator certificate and work experience above 10 years is relatively the same as the performance of lecturers who do not have an educator certificate and work experience under 10 years. In the group of lecturers do not have a certification teacher certification is not dominant because of the lack of conditions to be included in the proposed certification. the results showed that there were no significant differences in the performance of lecturers/

\section{CONCLUSION}

The performance of lecturers who already have an educator certificate is higher than the performance of lecturers who do not yet have an educator certificate, this also applies to lecturers who have work experience above 10 years who have higher performance than lecturers who have work experience under 10 years. And there is an influence of lecturer certification interaction and work experience on lecturer performance. Besides that, the performance of lecturers between those who have an educator certificate and work experience above 10 years is higher than the performance of lecturers who do not have an educator certificate and who have work experience of more than 10 years. The performance of the lecturers between those who already have an educator certificate and work experience under 10 years is relatively the same as the lecturer who does not have a certificate of education and work experience under 10 years. The performance of lecturers between those who have an educator certificate and work experience above 10 years is higher than the performance of lecturers who have had an educator certificate and who have work experience under 10 years. The performance of lecturers between those who do not have an educator certificate and work experience above 10 years is relatively the same as the performance of lecturers who do not have an educator certificate and who have work experience under 10 years.

\section{REFERENCE}

Arikunto, S. (2012). Dasar-dasar Evaluasi Pendidikan. Jakarta: Bumi Aksara.

Arends, Richard I. (1994). Learning to Teach. New York: McGraw-Hill Company.

Buku Pedoman Sertifikasi Pendidikan Untuk Dosen tahun 2010. Jakarta: Ditjen Dikti.

Buku Pedoman Sertifikasi Pendidik Untuk Dosen (Serdos) Terintegrasi: Buku 1 Naskah Akademik 2014. Jakarta: Ditjen PT Kemendikbud.

Cikmat, Sofyan. (2002). Kinerja: Seri Manajemen Sumberdaya Manusia. Jakarta: Elek Media Komputindo.

Danim, Sudarwan. (2008). Kinerja Staf dan Organsasi. Bandung: Pustaka Setia.

Departemen Pendidikan Nasional. (2008). Kamus Besar Bahasa Indonesia. Jakarta: Gramedia Pustakan Utama Jakarta.

Dessler, G. (2006). Manajemen Sumber Daya Manusia. Jakarta: PT. Indeks. Djaali dan Muljono, P. (2000). Pengukuran dalam Bidang Pendidikan. Jakarta: Grasindo.

Dunn. (2003). Pengantar Analisis Kebijakan Publik. Yogyakarta: Gadjah Mada University Press. Gomes, F.C. (2003). Manajemen Sumber Daya Manusia. Yogyakarta: Andi Offset.

Kurnia, Asep. (2006). "Hubungan Antara Etos Kerja, Pengalaman Keimigrasian, dan Iklim Organisasi Dengan Profesionalitas Pelayanan Petugas Imigrasi di Bandar Udara Soekarno-Hatta.” Disertasi, UNJ. 
Mangkunegara, A.A.P. (2011). Manajemen Sumber Daya Manusia Perusahaan. Bandung: Remaja Rosdakarya.

Nasution, S. (1995). Asas-Asas Kurikulum. Jakarta: Bumi Aksara.

Nawawi, H. (2011). Manajemen Sumber Daya Manusia Untuk Bisnis Kompetitif. Yogyakarta: Gajah Mada University Press.

Ocin, A. (2008). Kemampuan Mengajar Guru: Hubungan Antara Motivasi Berprestasi, Sikap Terhadap Profesi dan Pengalaman Mengajar Dengan Kemampuan Mengajar Guru. Disertasi UNJ.

Salamah. (2003). Kemampuan Mengajar Guru Sekolah Dasar: Suatu Studi tentang Hubungan antara Sikap terhadap Profesi Guru, Pengalaman Mengajar, dan Konsep Diri dengan Kemampuan Mengajar Guru di Sekoalah Dasar Kota Yogyakarta. Disertasi UNJ.

Solichin, A.W. (2014). Analisis Kebijakan: Dari Formulasi ke Penyusunan Model-Model Implementasi Kebijakan Publik. Jakarta: Bumi Aksara.

Suriasumantri, J.S. (2000). Filasafat Ilmu: Sebuah Pengantar Populer. Jakarta: Muliasari.

Sudijono, A. (2012). Pengantar Evaluasi Pendidikan. Jakarta: Raja Grasindo Persada.

Sudiyono. (2004). Manajemen Pendidikan Tinggi. Jakarta: Rineka Cipta.

Tayibnapis, Farida Yusuf. (2008). Evaluasi Program dan Instrumen Evaluasi untuk Program Pendidikan dan Penelitian. Jakarta: Rineka Cipta.

Whitmore, Jhon. (2002). Coaching For Performance: Membangun Individu, Kinerja, dan Sasaran. Jakarta: Bhuana Ilmu Populer. 